\title{
Neil E. Green, Marc F. Swiontkowski (eds): Skeletal trauma in children fourth edition
}

\author{
Saunders Elsevier, Philadelphia, 2009, Volume 3, 708 pp, num figs. \\ Hardcover XXX US \$, ISBN 978-1416049005
}

Pierre Kehr

Received: 15 August 2009 / Accepted: 18 August 2009 / Published online: 2 September 2009

(C) Springer-Verlag 2009

This book is exclusively devoted to infantile traumatology and is interesting in more than one way.

Initially it presents "the state of the art" in the treatment of the fractures. It is regrettable that treatment techniques as for example, the mailing technique of Metaizeau, are not mentioned; may be because this technique is not known outside France.

The chapters of general interest are particularly interesting because they give a progress report on subjects more rarely covered like the polytraumatized fractures, the fractures without traumatisms (syndrome of the beaten children), rehabilitation or the sport injuries.

Moreover, the indications are clearly posed, accompanied by rich iconography.

A good reference book.

No funds were received in support of this study.

Alain Graftiaux Strasbourg

P. Kehr $(\bowtie)$

ArgoSpine, Strasbourg, France

e-mail: kehrpier@aol.com 